\title{
Treatment of Prosthetic Joint Infection and Reconstruction of a Massive Shoulder Defect after Reverse Total Shoulder Replacement
}

\author{
Ji-An Choi (D), Jung-Ha Kwak (D), Kwang-Ryeol Lim (D), Chung-Min Yoon (D) \\ Department of Plastic and Reconstructive Surgery, Dong-A University School of Medicine, Busan, Korea
}

\begin{abstract}
Prosthetic joint infection is a rare but serious complication of total shoulder replacement. After infection control, shoulder reconstruction is also required to repair the shoulder defect. The shoulder is a complex structure consisting of mechanical soft tissue and the joint, making reconstruction challenging. A 78-year-old female patient was diagnosed of wound necrosis and exposed prosthesis due to prosthetic joint infection after reverse total shoulder replacement. The infection was controlled with appropriate antibiotic treatment, and the necrotic tissue was removed by radical debridement. To reduce the size of the massive shoulder defect and minimize exposure of the prosthesis, negativepressure wound therapy (NPWT) was administered for 8 weeks and shoulder reconstruction was performed using a pedicled latissimus dorsi (LD) flap and split-thickness skin graft. The patient recovered without any complications, and no reinfection of the surgical site or other complications were observed during follow-up visits. This report demonstrates that antibiotic treatment, radical debridement of necrotic tissue, NPWT, and shoulder reconstruction using a pedicled LD flap can be an effective method of treatment for prosthetic joint infection with exposed prosthesis, tissue necrosis, and massive shoulder defect.
\end{abstract}

Keywords: Shoulder; Superficial back muscles; Negative-pressure wound therapy

\section{서 론}

견관절 치환술 후 발생할 수 있는 합병증 중에 인공관절 주위 감염은 드물지만 심각하고 치료 가 힘든 합병증으로 알려져 있다[1]. 인공관절 주위 감염이 발생한 경우 항생제 치료에 동반하 여 주위 괴사 조직을 제거하고 이후 발생한 결손에 대하여 적절한 어깨 재건을 시행해야 한다 [2]. 하지만 인공관절 주위 연부 조직의 손상 및 미생물막 형성으로 감염 조절이 어렵고, 감염이 조절된 후에도 인공관절이 노출된 경우가 흔하며, 어깨의 구조가 복잡하여 어깨 재건이 쉽지 않다[3,4]. 저자들은 역행성 견관절 전치환술 후 발생한 인공관절 주위 감염을 성공적으로 치 료하고 이후 발생한 인공관절 노출이 동반된 어깨의 광범위한 결손을 광배근 유경피판을 이용 하여 성공적으로 재건한 사례를 문헌 고찰과 함께 보고하고자 한다. 출판을 위해 환자로부터 서면 동의를 받았다.

\section{증 례}

고혈압과 부정맥이 있었던 78세 여자 환자로 낙상 후 발생한 어깨 통증으로 1 주 뒤타병원에 내 원하여 어깨 탈구 및 오구돌기 골절을 진단받고 보전적 치료를 받았으나 증상에 호전 없어 본 원 정형외과에 방문하여 역행성 견관절 전치환술을 시행 받았다. 수술 후 가슴봉우리동맥 (thoracoacromial artery)의 첫 번째 가지 손상으로 수술 후 1 일째 수술 주위 부위 및 흥벽에 대 량의 혈종이 발생하였다. 이후 환자는 색전술을 시행 받아 급성 출혈은 호전되었고, 컴퓨터단
Case Report

Received: April 14, 2020

Revised: May 14, 2020

Accepted: May 17, 2020

Corresponding author: Chung-Min Yoon, M.D.

Department of Plastic and Reconstructive Surgery, Dong-A University School of Medicine, 26 Daesingongwon-ro, Seo-gu, Busan 49201, Korea

Tel: +82-51-240-2744

Fax: +82-51-243-5416

E-mail: ycm0924@dau.ac.kr

This is an Open Access article distributed under the terms of the Creative Commons Attribution Non-Commercia License (https://creativecommons.org/licenses/by-nc/4.0/) which permits unrestricted non-commercial use, distribution, and reproduction in any medium, provided the original work is properly cited.

(c) 2020 Korean Wound Management Society 
층촬영(computed tomography)상 견관절 치환물은 잘 고정되어 있는 것이 확인되었으나, 어깨 부위의 지속된 창상 파열 및 괴사 소견으로 수술 후 2 주째 본과에 협진 의뢰되었다. 의뢰 시 환자의 우측 어깨에 $10 \times 10 \mathrm{~cm}$, 가슴에 $5 \times 5 \mathrm{~cm}$ 크기의 창상 괴사 소견이 관찰되었다. $\mathrm{Fig}$. 1). 창상은 가피에 덮여 있었고 가피 결손 부위 아래로 악취를 동반한 대량의 혼탁한 분비물이 어깨와 가슴의 가피, 그리고 흥벽 사이에 고 여 있었다. 가피 제거 시 지방 괴사 소견이 관찰되었고 근육의 형태는 확인되지 않았다. 분비물의 배출을 위하여 가피 및 주위 지방 괴사조 직을 제거하였고 분비물에 대한 세균 배양 검사를 시행하였다. 혈액 검사상 백혈구 $12,730 / \mathrm{mm}^{3}$, 적혈구 침강속도 $34 \mathrm{mmHg} / \mathrm{hr}, \mathrm{C}$-반응성 단백 $15.03 \mathrm{mg} / \mathrm{L}$ 로 관찰되었고, 창상 주위 분비물에 대한 세균 배양 검사상 응고효소 음성 포도상구균이 검출되었다. 감염 내과 협진 하 에 정맥 항생제 vancomycin $1 \mathrm{~g}$ (1일 2회)와 aztreonam $2 \mathrm{~g}$ (1일 3회)을 8 주간 유지하며 매일 대량 세척과 무균적 소독을 지속하였다. 정맥 항생제 사용 3 주 뒤 시행한 혈액 검사상 백혈구 $6,260 / \mathrm{mm}^{3}$, 적혈구 침 강속도 $3 \mathrm{mmHg} / \mathrm{hr}, \mathrm{C}$-반응성단백 $0.90 \mathrm{mg} / \mathrm{L}$ 로 감소하였고, 창상 주 위 분비물에 대한 세균 배양 검사상 균음전 소견이 관찰되었다. 수술 후 8 주째 창상의 경계가 명확히 관찰되어 광범위하게 죽은 조직 제거 술을 시행하였다. 어깨의 $15 \times 15 \mathrm{~cm}$ 크기의 개방성 창상 내부로 인공 관절이 노출되어 있고 인공관절 주위로 육아조직이 형성되어 있었으 나 정상적인 근육 및 인대 등의 구조물은 관찰되지 않았다. 가슴의 7 $\times 5 \mathrm{~cm}$ 크기의 창상은 피부 결손으로 인하여 피하 지방이 노출되어 있었으며 어깨의 개방성 창상과 흥벽을 따라 연결되어 있었다(Fig. 2).

수술 후 8 주부터 16 주까지 8 주간 각각의 창상에 음압 창상 치료를 주 2-3회 시행하였다. 음압창상 치료 시행 8 주 후 어깨창상의 인공관

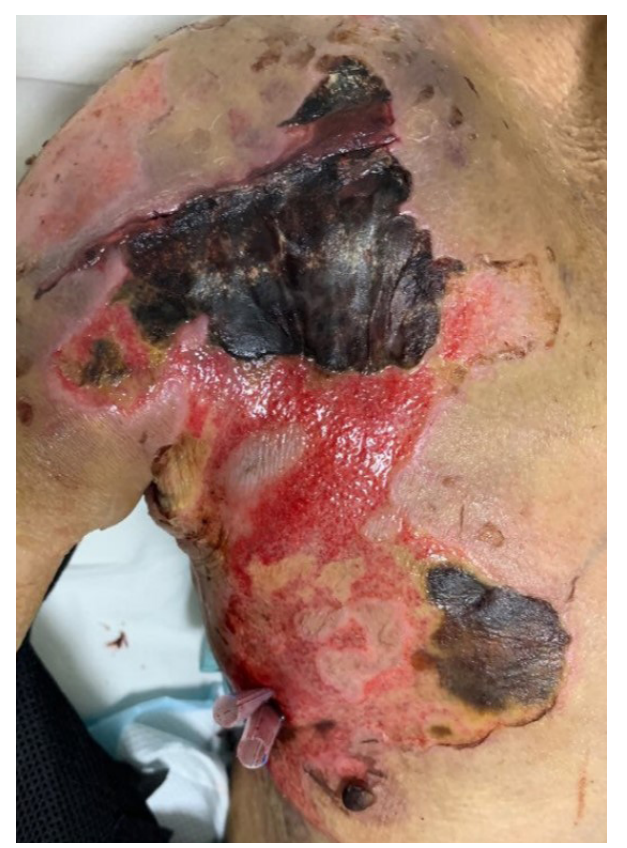

Fig. 1. Preoperative view: wound prior to radical debridement.
절은 여전히 노출되어 있었으나 인공관절 주위로 육아조직이 형성되 며 결손의 크기가 $12 \times 10 \mathrm{~cm}$ 로 감소하였고, 가슴 창상도 결손의 크기 가 $5 \times 5 \mathrm{~cm}$ 로 감소하였다(Fig. 3). 이에 전신 마취 하에 광배근 유경피 판술을 이용하여 어깨 재건을 시행하고, 가슴의 피부 결손 부위에는 부분층피부 이식을 시행하였다(Fig. 4).

수술 4 주 뒤 환자는 특이 합병증 없이 호전되었으며 수술 후 재활 치료 계획 수립을 위하여 정형외과로 전과 후 1 주 뒤 퇴원하였다. 환 자는 수술 후 1 년간 창상의 재발이나 합병증 소견 없이 경과 관찰 중 이다. 혈종 발생시부터 동반되어 있었던 상완신경총 손상에 대한 재 활 치료를 위하여 퇴원 후 타병원으로 통원 치료를 하고 있으나, 고령 의 환자로 재활 치료에 대한 순응도가 떨어져 어깨 기능의 호전은 유 의미하게 관찰되고 있지는 않다.

\section{고 찰}

어깨 관절의 회전근개 질환이나 퇴행성 질환이 증가함에 따라 견관 절 치환술의 시행이 증가하고 이에 따른 합병증의 발생도 증가하고 있다[5]. 견관절 치환술 후 인공관절 주위 감염의 발생률은 약 $1 \%$, 이 중 본 증례와 같은 역행성 견관절 전치환술 후에는 그보다 높은 $3.8 \%$ 로보고되고 있다[1,6].

인공관절 주위 감염으로 인한 심부 감염은 주위 조직에 대한 세균 배양을 통한 적절한 항생제 치료와 병행하며 세척 및 죽은 조직의 광 범위 절제 후, 필요시 어깨 재건 및 치환물의 교체를 시행하여야한다 [2]. 인공관절 주위 감염은 관절의 불안정성과 더불어 역행성 견관절 치환술 후 재치환술을 고려하여야 하는 가장 흔한 합병증 중 하나이

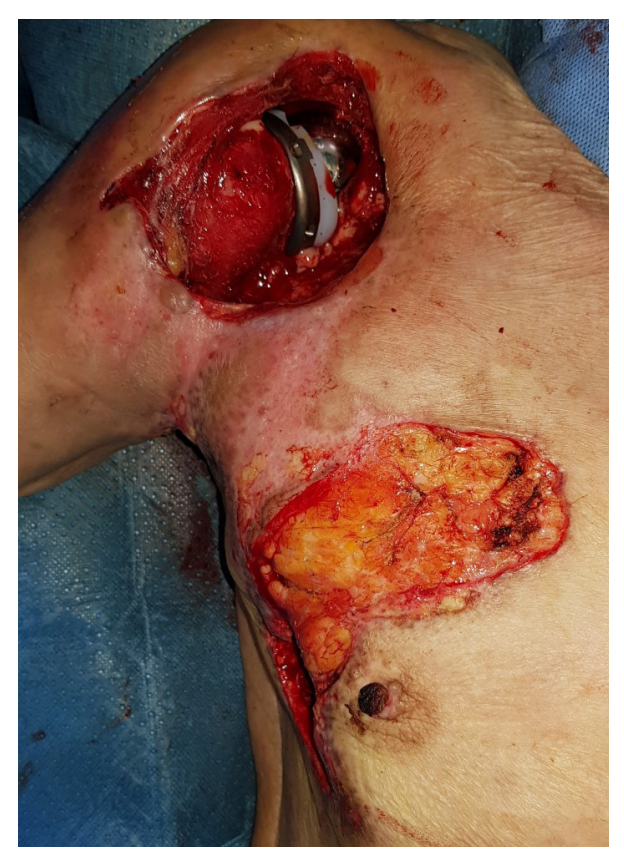

Fig. 2. Immediate postoperative view: wound after radical debridement. 
Choi JA et al.

Reconstruction of shoulder

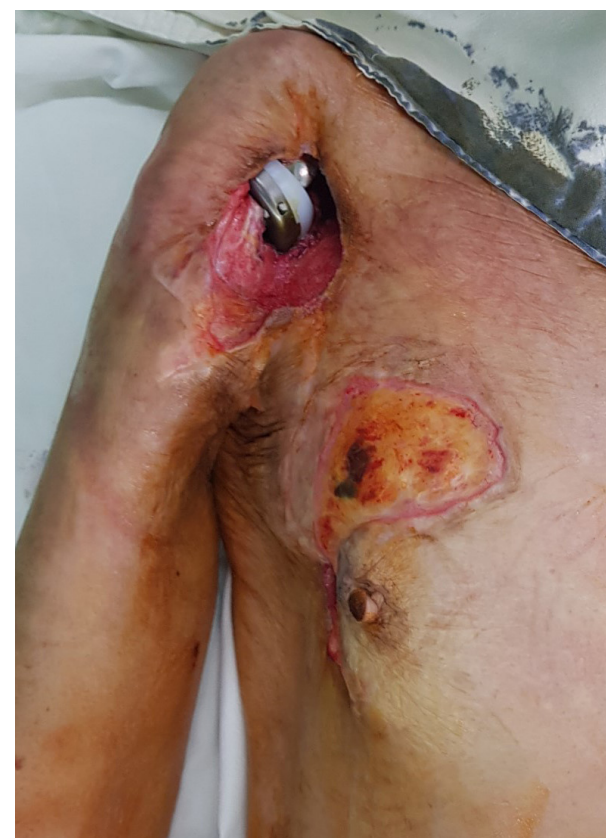

Fig. 3. Postoperative view: after 8 weeks of serial negative-pressure wound therapy.

다[7]. 하지만, 재치환술을 하는 경우 결과 및 예후는 일차적으로 치 환술을 시행 받았던 진단 및 재치환을 하게 되는 원인에 따라 많은 차이를 보이고 연부조직 결손으로 인한 재치환술의 경우 골 결손으 로 인해 재치환을 하는 경우보다 높은 합병증 발생률이 보고되고 있 고, 예후도 불량한 것으로 알려져 있다[5]. 항생제 사용 기간, 재치환 술의 필요 여부, 재치환술의 시행 시기 등 인공관절 주위 감염의 발생 시 치료 원칙에 대하여는 아직 논란의 여지가 있어, 치료의 결과에 영 향을 미칠 수 있는 다양한 요소들을 고려하여 환자에게 가장 적절한 치료 방법을 선택하는 것이 중요할 것으로 생각된다[7]. 이전에 보고 되었던 논문에 따르면 수술 후 4 주에서 6 주 이내에 급성 감염이 발생 한 고령 환자에서, 창상 주위 균 배양 검사상 항생제 치료에 반응이 좋은 균이 배양되고, 치환물이 잘 고정되어 있어 불안정성이 발생하 지 않은 경우, 연부 조직으로 어깨 재건이 가능하다면 치환물을 보존 하는 것을 고려해 볼 수 있을 것으로 권고되었다[8]. 이에 본 증례에서 는 79세 고령 환자에서 수술 후 4 주 이내 발생한 급성 감염으로 수술 후 시행한 영상학적 검사상 치환물이 잘 고정되어 있었으며 항생제 치료 후 균의 음전이 확인되어 치환물을 보존하여 연부 조직 결손의 재건을 시행하여 인공관절 주위 감염의 치료에 좋은 결과를 얻을 수 있었다.

재치환술을 하지 않고 인공관절 주위 감염이 조절된 이후 발생한 어깨의 피부 및 연부 조직의 광범위한 결손에 대하여 적절한 재건이 필요하다. 일반적으로 어깨 결손은 육종 등과 같은 연부조직의 절제 나, 외상, 만성 창상 또는 만성 창상의 광범위 죽은 조직 제거술 후 흔 하게 발생하는 것으로 알려져 있다[9]. 어깨는 인간의 관절 중 가동 범위가 가장 넓은 관절 중 하나로 구조가 복잡하고 볼록한 형태를 이

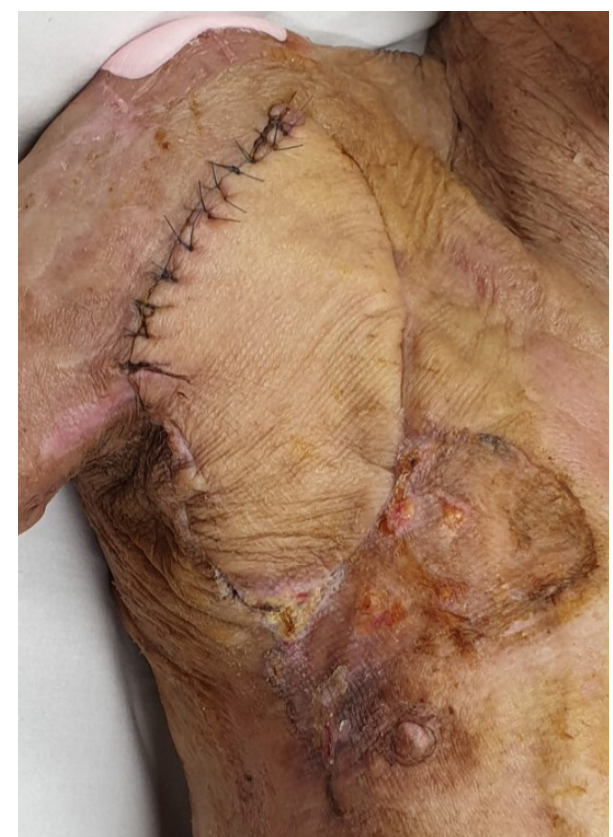

Fig. 4. Four weeks after shoulder reconstruction with pedicled latissimus dorsi flap.

루고 있으며, 본 증례와 같이 인공관절 주위 감염이 있었던 경우에는 삽입물이나 뼈의 노출이 동반된 경우가 흔하여 재건이 쉽지 않다 $[3,4]$. 어깨 재건 시 일차 봉합은 추후 구축으로 인한 어깨 움직임의 제한을 가져올 수 있어 결손의 크기가 작고 양측의 장력이 적으며 중 요한 구조물의 노출이 없는 경우에만 제한적으로 시행할 수 있다[4]. 이에 창상의 상태에 따라 적절한 근육 피판을 이용한 결손의 재건이 중요하다.

1906년 Tasini에 의해 처음 소개된 이래 광배근 유경피판은 어깨 재건을 위한 좋은 공여부로 고려돼왔다[4]. 광배근 유경피판은 부채 꼴 형태의 큰 근육을 포함하고 있어 불룩한 어깨의 형태를 복원하기 에 충분한부피를 제공해줄수 있으며, 수여부에 혈관이 풍부한 넓은 표면을 제공할 수 있어감염 위험도를 낮출 수 있다[4]. 또한 흥배동맥 이 피판에 길고 튼튼한 혈관경을 제공해 주어 어깨 뒷면, 윗면, 앞면 의 결손까지 재건이 가능하다[10]. 특히 본 증례와 같이 어깨 앞면의 결손에 대한 재건 시 광배근 유경피판이 불가능한 경우에는 대안적 으로 대흥근 및 소흥근을 이용한 피판이 제한적인 경우 대안적으로 사용될 수 있으나 대부분의 경우 유리 피판이 유일한 방법으로 고려 되고 있다[10]. 본 증례에서는 환자의 흥배동맥 손상이 없음을 확인 후 어깨 앞면의 광범위 어깨 결손을 광배근 유경피판을 이용하여 재 건하였다.

저자들은 역행성 견관절 전치환술 후 발생한 혈종과 인공관절 주 위 감염 및 그로 인해 발생한 인공관절 노출이 동반된 어깨 결손을 적 절한 항생제 치료 및 광범위 죽은 조직 제거술, 음압 창상 치료, 그리 고 광배근 유경피판을 이용한 어깨 재건을 통하여 성공적으로 치료 할 수 있었다. 이에 본 치료 경험을 문헌고찰과 함께 보고하는 바이다. 


\section{Conflict of interest}

This study was supported by the research funds of Dong-A University. Otherwise, no potential conflicts of interest relevant to this article are reported.

\section{ORCID iDs}

Ji-An Choi https://orcid.org/0000-0003-4125-8043

Jung-Ha Kwak https://orcid.org/0000-0003-3079-9223

Kwang-Ryeol Lim https://orcid.org/0000-0001-8947-4154

Chung-Min Yoon https://orcid.org/0000-0003-0307-5545

\section{References}

1. Padegimas EM, Maltenfort M, Ramsey ML, et al. Periprosthetic shoulder infection in the United States: incidence and economic burden. J Shoulder Elbow Surg 2015;24:7416.

2. Tande AJ, Patel R. Prosthetic joint infection. Clin Microbiol Rev 2014;27:302-45.

3. Oh J, Ahn HC, Lee BG. Functional and aesthetic reconstruction of shoulder using pedicled LD flap after radical debridement of tuberculosis infected rheumatoid arthritis wound. J Wound Management and Research 2018;14:132-
6.

4. Behnam AB, Chen CM, Pusic AL, et al. The pedicled latissimus dorsi flap for shoulder reconstruction after sarcoma resection. Ann Surg Oncol 2007;14:1591-5.

5. Kim YK, Jung KH. Etiology and treatment of revision shoulder arthroplasty. J Korean Orthop Assoc 2019;54:1009.

6. Zumstein MA, Pinedo M, Old J, et al. Problems, complications, reoperations, and revisions in reverse total shoulder arthroplasty: a systematic review. J Shoulder Elbow Surg 2011;20:146-57.

7. Markes AR, Cheung E, Ma CB. Failed reverse shoulder arthroplasty and recommendations for revision. Curr Rev Musculoskelet Med 2020;13:1-10.

8. Sperling JW, Kozak TK, Hanssen AD, et al. Infection after shoulder arthroplasty. Clin Orthop Relat Res 2001;(382): 206-16.

9. $\mathrm{Ma} \mathrm{CH}, \mathrm{Tu} \mathrm{YK}, \mathrm{Wu} \mathrm{CH}$, et al. Reconstruction of upper extremity large soft-tissue defects using pedicled latissimus dorsi muscle flaps: technique illustration and clinical outcomes. Injury 2008;39 Suppl 4:67-74.

10. Engdahl R, Disa J, Athanasian EA, et al. Pedicled latissimus dorsi flap for shoulder soft-tissue reconstruction after excision of a musculoskeletal neoplasm: version 2. JBJS Essent Surg Tech 2016;6:e16. 